ROCZNIKI TEOLOGICZNE

Tom LXVIII, zeszyt 9 - 2021

DOI: https://doi.org/10.18290/rt.21689.6

\title{
ŚRÓDZIEMIE „ZAPOWIADAJĄCE” NOWE PRZYMIERZE. PROPOZYCJA SPOSOBU INTERPRETACJI LEGENDARIUM J.R.R. TOLKIENA
}

\author{
MIDDLE-EARTH AS ANNOUNCING THE GOSPEL. \\ SUGGESTION OF THE WAY OF INTERPRETATION FOR WORKS OF J.R.R. TOLKIEN
}

\begin{abstract}
A b s t r a c t. The article addresses the issue of relationship between theology and literature. The purpose is to find a proper method for theological interpretation of literature. Proposed method is St. Paul's category of "figure" - the phenomenon, person or object that announces another from the New Testament. Firstly the paper defines the concept of ,figure” and presents its history. Next the article explains the objective and conditions of using the method to interpret some parts from J.R.R. Tolkien's The Silmarillion. The last part of the text is the example of application of the method to a story of The Journey of Elves from III-V chapters of The Silmarillion. The analysis presents the story as the image of the Church in its way to heaven. The work shows that the literature can be interesting for theology and that theology can interpret the works of literature. The "figure" methodology is one of the accurate ways to understand the literature in theology.
\end{abstract}

Keywords: literature; Tolkien; figure; Church.

Chrześcijańskość dzieł J.R.R. Tolkiena, na czele z Władca Pierścieni, przyjmowana jest z pewną rezerwą, między innymi dlatego, że nie da się ich łatwo interpretować alegorycznie (w przeciwieństwie np. do Opowieści z Narnii jego przyjaciela C.S. Lewisa ${ }^{1}$ ). $\mathrm{Z}$ drugiej strony, pełne są one postaci i motywów

Mgr lic. Magdalena GolanowsKa - doktorantka, Uniwersytet Papieski Jana Pawła II w Krakowie, ul. Kanonicza 20/8, 31-002 Kraków; e-mail: magdalena0403@o2.pl. ORCID: https://orcid.org/0000-0003-2274-2091.

${ }^{1}$ Por. np. Paolo Gulisano, C.S. Lewis. Od Narnii do Ewangelii (Poznań: W drodze, 2006), 152-158. 
zdających się przywoływać religijną - wprost chrześcijańską - treść ${ }^{2}$. Niniejszy artykuł stanowi próbę zaproponowania kategorii interpretacyjnej, odpowiedniej dla legendarium Tolkiena, która pozwoli uchwycić jego subtelny przekaz, oraz przykład zastosowania jej na jednym z fragmentów Silmarillionu ${ }^{3}$.

\section{POJECIE TYPU W TEOLOGII}

Typ (gr. $\tau u ́ \pi o \varsigma$ - typos) - w znaczeniu biblijnym to „osoba, przedmiot lub wydarzenie biblijne, zazwyczaj ze Starego Testamentu, które jest zapowiedzią przyszłych rzeczywistości: osób, przedmiotów lub wydarzeń w Nowym Testamencie" ". Jest to pojęcie zaczerpnięte z teologii św. Pawła, dokładniej z Listu do Rzymian, gdzie pisze o Adamie: „On to jest typem Tego, który miał przyjść" [Chrystusa] (Rz 5,14). Przedstawia on, na zasadzie zarówno podobieństwa jak i antytezy Adama, jako zapowiedź Chrystusa. Paralelę tę rozwija w Rz 5,12-19 oraz w 1 Kor 15,45-49. Ta kategoria myślenia jest nieobca także innym księgom Nowego Testamentu. Historia Noego odczytywana jest jako zapowiedź chrztu (1 P 3,19-21), arcykapłan Melchizedek jako wskazujący na wieczne kapłaństwo Chrystusa (Hbr 6,19-7,12), a ofiara Izaaka - na Jego śmierć i zmartwychwstanie (Hbr 11,17-19). Typologia stanowiła również metodę interpretacyjną teologów okresu patrystycznego. Warto w tym miejscu wspomnieć na przykład rozwijaną przez Ireneusza z Lyonu w Adversus Haereses analogię Ewa - Maryja ${ }^{5}$, będącą swego rodzaju dopełnieniem Pawłowej: Adam - Chrystus. Na uwagę zasługuje również dzieło św. Hilarego z Poitiers Traktat o Tajemnicach, w całości składający się z przykładów postaci Starego Testamentu będących w różnych aspektach zapowiedziami tajemnicy Chrystusa i Kościoła. Mówi on o Adamie, Ablu, Lameku, Noem, Abrahamie, Izaaku, Jakubie, Mojżeszu, Ozeaszu i Jozuem6. Myślenie typolo-

\footnotetext{
${ }^{2}$ Jednym z najwyraźniejszych tego przykładów pozostaje lembas - chleb elfów, chleb na drogę mogący jednym kęsem sycić na wiele dni. Por. John R.R. Tolkien, Władca Pierścieni. Drużyna Pierścienia (Warszawa: Amber, 2012), 407.

${ }^{3}$ Wtadca Pierścieni i Silmarillion stanowią w pewnym sensie jedną całość, opowiadają różne fragmenty historii tego samego świata. Wtadca Pierścieni w równym stopniu jest kontynuacją Hobbita co Silmarillionu, jednak ten ostatni jako trochę mniej znany stanowi świeże i ciekawe pole do badań.

${ }^{4}$ Por. Typ, w Pismo Święte Starego i Nowego Testamentu Biblia Tysiaclecia, wyd. V, dodatek Stownik pojęć biblijnych (Poznań: Pallottinum, 2008).

${ }^{5}$ Por. Ireneusz z Lyonu, Adversus Haereses (Pelplin: Bernardinum, 2018), 471-472.

${ }^{6}$ Hilary z Poitiers, O tajemnicach (Warszawa: Wydawnictwo Uniwersytetu Kardynała Stefana Wyszyńskiego, 2002).
} 
giczne jest nadal żywe w liturgii i pobożności Kościoła. Najcharakterystyczniejszym przykładem tej ostatniej są Godzinki o Niepokalanym Poczęciu Najświętszej Maryi Panny - w poetyckiej formie utkane z odczytanych typicznie motywów starotestamentalnych. Posługuje się nim także Sobór Watykański II ${ }^{7}$.

Istotne pozostaje zagadnienie relacji typologii do alegorii. M. Simonetti uważa odczytanie typiczne za jedynie jedną z jej form ${ }^{8}$. Natomiast A.T. Hanson zdaje się uznawać alegorię za wynaturzoną, posuniętą do przesady formę typologii ${ }^{9}$. Istotnie ich granice nieraz sa nieostre i mocno zniuansowane. U wielu autorów (np. sens duchowy u Orygenesa) trudno jednoznacznie rozstrzygnąć, czy posługują się oni typologią czy alegorią. Obie metody bazują na założeniu, że całe Pismo mówi o Chrystusie, a teksty biblijne mogą mieć więcej niż wyłącznie jeden - dosłowny - sens. Chociaż takie rozróżnienia z konieczności są nieco sztuczne i upraszczające, niemniej pozostają konieczne dla jasności dyskursu. Wydaje się, że można wskazać na poniższe elementy jako charakteryzujące typologię i odróżniające ją od alegorii:

1. Typ zachowuje swoją tożsamość i realność. W pierwszej kolejności „oznacza” sam siebie, dopiero wtórnie wskazuje na swoją realizację - antytyp. W alegorii jedna rzeczywistość oznacza wprost drugą i niejako rzecz oznaczająca znika wobec oznaczanej.

2. Typ pozostaje zawsze „mniejszy” od antytypu. Stanowi jedynie zapowiedź, podczas gdy antytyp przynosi pełnię rzeczywistości zapowiadanej. W alegorii zaobserwować można jeśli nie równorzędność oznaczającego i oznaczanego, to przynajmniej proporcjonalność pomiędzy relacjami poszczególnych elementów alegorii i rzeczywistości.

3. Typ wykazuje pewne podobieństwo do antytypu - na którym może bazować porównanie - ogranicza się ono jednak do wybranych aspektów wydarzenia czy postaci, podczas gdy inne pozostają niejako na marginesie, nie stanowia podobieństwa i nie wchodza w skład typologii. W alegorii natomiast niemal każdy, najdrobniejszy element nabiera znaczenia przenośnego.

4. Typologia może być zbudowana zarówno na zasadzie podobieństwa, jak $\mathrm{i}$ antytezy, i to nieraz w odniesieniu do tej samej pary typ - antytyp. Alego-

\footnotetext{
${ }^{7}$ Por. „Konstytucja dogmatyczna o Kościele Lumen gentium”, nr 6, w Sobór Watykański II, Konstytucje, dekrety, deklaracje. Tekst polski - nowe ttumaczenie (Poznań: Pallottinum, 2002).

${ }^{8}$ Manlio Simonetti, Między dostownościa a alegoria: przyczynek do historii egzegezy patrystycznej (Kraków: WAM, 2000), 22.

9 A.T. Hanson, Typologia, w Stownik wiedzy biblijnej, red. Bruce M. Metzger, Michael D. Coogan (Warszawa: Vocatio, 2004), 780-781.
} 
ria musi być bardziej spójna i bazuje jedynie na podobieństwie, a nie na przeciwieństwie.

Typ jest więc kategorią bardziej dynamiczną i niedookreśloną niż alegoria. Charakteryzuje go w związku z tym większa otwartość na interpretację i, jeśli można tak powiedzieć, pokora wobec tajemnicy. Zaprasza i wskazuje rzeczywistość, która wyraźnie mu się wymyka i nie ma ,ambicji”, by obją́ ją kompleksowo i ze szczegółami. W niniejszym artykule pojęcie typu będzie używane w takim sensie.

\section{ZASTOSOWANIE KATEGORII TYPU W INTERPRETACJI PROZY TOLKIENA}

Kategoria typu okazuje się niezwykle pomocna w interpretacji Silmarillionu J.R.R. Tolkiena. Mimo że jest on mniej znany niż Władca Pierścieni, pozostaje dla niego nieodzownym tłem i podbudową. Stanowi on zbiór mitów Śródziemia, zapis jego historii od stworzenia świata, opisywanej oczami elfów. Całość narracji złożona z różnych bardziej i mniej dopracowanych legend opiera się na historii wspaniałych kamieni Silmarili oraz poszczególnych rodów elfów, ich relacji ze sobą nawzajem i zmagań z zagrażającym Śródziemiu złem.

Świat przedstawiony stworzony przez Jedynego - Eru Ilúvatara składa się z dwu kontynentów - Śródziemia, w którym odbywa się większość akcji Tolkienowskich opowieści, i Valinoru (Amanu) - Błogosławionego Królestwa, siedziby Valarów - potężnych istot duchowych stworzonych przez Eru, porównywanych do Aniołów lub bogów ${ }^{10}$. W miarę jego trwania pojawiają się w nich rasy rozumne, Dzieci Ilúvatara, najpierw Pierworodni - elfowie, dużo później Następcy - ludzie ${ }^{11}$. Źródłem zła i cierpienia w świecie są duchy zbuntowane pod wodzą najpotężniejszego z nich - Melkora zwanego Morgothem ${ }^{12}$.

Zarówno w Silmarillionie, jak i Władcy Pierścieni pojawiają się liczne postaci i motywy, które zdają się nawiązywać do pojęć chrześcijańskich i przenosić religijną treść. Ich interpretacja i identyfikacja nastręcza jednak pewnych problemów i wymaga odpowiednich narzędzi. Tutaj z pomocą przychodzi właśnie pojęcie „typ”. Pozostaje ono uprawnioną i być może, obok

\footnotetext{
${ }^{10}$ Por. John R.R. Tolkien, Silmarillion (Warszawa: Amber, 2008), 44

11 Por. tamże, 61-62.

12 Por. tamże, 51-52.
} 
interpretacji teologiczno-moralnej ${ }^{13}$, jedną $\mathrm{z}$ najowocniejszych teologicznie metod interpretacji tego dzieła. Interpretację taką uzasadniają dwa fakty.

Sam Tolkien był przeciwnikiem prostych alegorii, uznawał jednak chrześcijańską wymowę, symbolikę swoich dzieł. W liście do Miltona Waldmana pisał: „nie lubię alegorii - świadomej i zamierzonej alegorii, a jednak każda próba wyjaśnienia sensu mitu czy baśni musi posługiwać się językiem alegorycznym"14. Dopuszczał więc możliwość symbolicznego rozumienia jego dzieł. W jego optyce jednak odczytanie alegoryczne jest wtórne do samej opowieści, nie zaś odwrotnie - opowieść dla ukazania alegorycznie treści. Wyraża to w ten sposób: „im więcej opowieść ma 'życia', tym bardziej będzie podatna na alegoryczne interpretacje; podczas gdy im lepiej będzie zrobiona zamierzona alegoria, tym bardziej będzie do przyjęcia jako zwykła opowieść"15. W innym liście znajdujemy słowa: ,jest to dzieło zasadniczo religijne i katolickie, początkowo niezamierzenie, ale w poprawkach świadomie" ${ }^{\text {"16 }}$, odnoszą się one co prawda nie do Silmarillionu, a do Wtadcy Pierścieni, jednak ukazują one spojrzenie autora na całość legendarium.

W zamyśle autora Silmarillion ma stanowić mit czy też zbiór mitów. Opowieść o czasach tak zamierzchłych, że niemożliwych do udokumentowania historycznego i niemal już zapomnianych, a jednak ciągle mających znaczny wpływ na obraz świata i przekazujących jakąś prawdę o nim. Zapis historii otwartej na sacrum. Co kluczowe, Tolkien postrzegał swoje dzieło jako rekonstrukcję mitologii dla Anglii ${ }^{17}$, w związku z tym można je uznać za swego rodzaju fikcyjną historię rzeczywistego świata.

Należy przy tym poczynić następujące zastrzeżenia co do zastosowania metody typologicznej do Silmarillionu:

1. Aby można było w ogóle analizować teologicznie mity i dzieła stylizowane na mity, potrzebne jest zasadnicze założenie co do religii niechrześcijańskich. O tyle interpretacja taka ma sens, o ile są one raczej „przed-chrześcijańskie” niż „pogańskie”, o ile stanowią praeparatio Evangelica ${ }^{18}$. Tak

\footnotetext{
${ }^{13}$ Por. np. Alena Androsik, Misja Powiernika Pierścienia jako przyktad realizacji powołania chrześcijańskiego. Studium teologicznomoralne na podstawie „,Władcy Pierścieni” J.R.R. Tolkiena (Lublin: Polihymnia, 2015).

14 Por. John R.R. Tolkien, Listy (Warszawa: Prószyński i S-ka, 2010), 240.

${ }^{15}$ Por. tamże.

16 Por. tamże, 282.

17 Por. tamże, 239.

18 Por. Lumen gentium, nr 16.
} 
je postrzegał Tolkien ${ }^{19}$, dlatego uzasadnione pozostaje poszukiwanie w jego dziele elementów wskazujących na orędzie Ewangelii i wyrażających tęsknotę za jej nadejściem.

2. Typologia pozostaje metodą teologii biblijnej. Może ona zostać przeniesiona do interpretacji dzieł, takich jak Silmarillion, ale przy tym zmienia ona nieco swój charakter. Pozostaje metodą nie własną, przystosowaną, niemniej może być użyteczną w odczytaniu i zrozumieniu dzieła.

3. Oczywiste jest, że Silmarillion nie jest tekstem natchnionym. Zastosowanie do niego metodologii właściwej badaniom biblijnym nie ma na celu nadania mu lub sugerowania takiego charakteru czy rangi.

4. Elementy odczytywane jako typiczne mogą być traktowane jako swego rodzaju „zapowiedź” czy przygotowanie na przyjęcie Ewangelii, ponieważ autor osadza swoją opowieść w mitycznej przeszłości świata. Jednocześnie jest on jednak chrześcijaninem i zna rzeczywistość zapowiadaną, i z tej perspektywy bardziej lub mniej świadomie umieszcza w swoim dziele jej ślady. W związku z tym trzeba tu mówić o tworzeniu postaci i zjawisk typicznych wtórnie - stąd proponowane przeze mnie określenie „retypizacja”.

5. Metoda ta może być zastosowana do licznych postaci i wydarzeń świata przedstawionego, ale jest użyteczna w interpretacji raczej fragmentów niż sensu całości. Nie pozostaje ona jednak bez znaczenia dla interpretacji całego dzieła. Pozwala na zobaczenie świata przedstawionego jako świata otwartego na działanie Boga i oczekującego, nawet jeśli w sposób mocno nieuświadomiony, nadejścia Mesjasza.

Należy także zaznaczyć, że odczytanie typiczne w tym artykule dokonywane jest z perspektywy teologii współczesnej i nie rości sobie pretensji do odkrycia jedynego czy nawet bezpośrednio zamierzonego przez autora sensu dzieła.

\section{WEূDRÓWKA ELFÓW OBRAZEM KOŚCIOŁA PIELGRZYMUJĄCEGO}

Jednym z bardzo bogatych obrazów, które mogą być zinterpretowane w kluczu typicznym, jest opowieść o Wielkiej Wędrówce elfów do Błogosławionego Królestwa Valinoru.

Ma ona miejsce już na początku historii elfów, niedługo po ich przebudzeniu się na świecie. Valarowie w swoim pragnieniu wszystkiego co najlepsze

\footnotetext{
${ }^{19}$ Por. Tolkien, Listy, 239.
} 
dla Dzieci Ilúvatara wzywają ich do zamieszkania w Valinorze. Elfowie boja się jednak Valarów, bo po raz pierwszy zobaczyli ich wyruszających na wojnę przeciwko Melkorowi. Najpierw więc do Valinoru udaje się trzech posłów - późniejszych królów trzech rodów elfów: Ingwë, Finwë i Elwë. Urzeczeni pięknem krainy i majestatem Valarów, po powrocie popierają zaproszenie bogów, namawiając swoich współplemieńców do wyruszenia w podróż. Nie wszyscy elfowie decydują się jednak wyruszyć. Wielu wolało pozostać w ziemi swego pochodzenia, przedkładając nad blask Drzew światło gwiazd i otwarte przestrzenie Śródziemia. Pozostali wyruszają na Zachód. Podróżują w trzech grupach - plemionach: Vanyarom przewodzi Ingwë, Noldorów wiedzie Finwë, zaś Telerich Elwë, a następnie Olwë, jego brat. Wędrówka ta trwa bardzo długo, bowiem każde mijane miejsce jest dla elfów nowe i zachwycające, często zatrzymują się więc w drodze. Wielu też do tego stopnia zachwyca się samą wędrówką, że zwleka jak tylko może z osiągnięciem jej celu. Vanyarowie i Noldorowie pierwsi docierają na zachodni brzeg Śródziemia i stamtąd Ulmo na wielkiej wyspie przenosi ich do Amanu. Droga Telerich jest bardziej skomplikowana, w Beleriandzie bowiem ich wódz Elwë zakochuje się w Melianie i przez wiele lat nikt nie może go odnaleźć. Kiedy Ulmo wzywa wszystkich elfów do przeprawy, Teleri usłyszeli jego wezwanie zbyt późno, by zdążyć odpłynąć ze wszystkimi, nie chcieli zresztą odpływać bez swego wodza, dlatego na długie lata pozostali na wybrzeżu, zaprzyjaźniając się z Ossëm, jednym z Majarów ${ }^{20}$ związanych z morzem. Wreszcie za przyczyną Noldorów również i oni otrzymali możliwość przeprawienia się na tej samej co tamci wyspie do granic Błogosławionego Królestwa i większość z nich (z wyjątkiem tych, którzy woleli zaczekać na Elwëgo) wyrusza w tę drogę. Ze względu jednak na przywiązanie do morza i przyjaźń z Ossëm wypraszają zakotwiczenie wyspy pośrodku drogi, w miejscu, z którego widać już Aman. Po kolejnym długim odcinku czasu część z nich uczy się budować okręty i dzięki nim ostatecznie dociera do Valinoru ${ }^{21}$.

Opis wędrówki wykazuje pewne podobieństwa do wędrówki narodu wybranego do Ziemi Obiecanej. Elfowie prowadzeni są przez Oromëgo, podobnie jak Izraelici przez słup obłoku, idą przez wiele lat i zatrzymują swój marsz, nieraz na długi czas, póki nie dostaną od niego sygnału do ponownego wymarszu. Podobny jest również motyw posłańców/zwiadowców, którzy po

\footnotetext{
${ }^{20}$ Majarowie to pomniejsze anielskie duchy podobne do Valarów i służące im. Należy do nich między innymi także Meliana.

21 Tolkien, Silmarillion, 74-85.
} 
odwiedzeniu celu marszu wszystkich, mają zdać sprawę z tego, co tam zobaczyli. W przeciwieństwie do zwiadowców z Księgi Liczb, ci są jednak zgodni i prawdomówni - nie zniechęcają do marszu, lecz zachęcają poprzez świadectwo o wszystkich cudach krainy. To powiązanie $z$ wędrówką Izraela do Kanaanu sugeruje typiczny charakter wędrówki elfów. Można ją odczytać jako obraz Kościoła - ludu pielgrzymującego do niebiańskiej ojczyzny. Na wyakcentowanie zasługują następujące elementy narracji:

Wezwanie

Wędrówka Elfów nie jest ich własną inicjatywą. Zostali oni zaproszeni przez Władców Zachodu do udziału w światłości i szczęściu. Jest to wolna decyzja Valarów motywowanych miłością i pragnieniem dobra elfów ${ }^{22}$. Podobnie Kościół jest umiłowany przez Boga, stanowi nowy lud wybrany

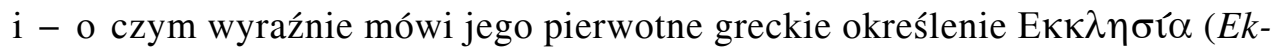
klesia) - lud wezwany, wywołany ze świata, by uczestniczyć w światłości i pełni szczęścia Życia Bożego (por. 1 P 2,9-10) ${ }^{23}$.

Powszechność $i$ wolność

Wyraźnie widoczne są także komplementarne rysy powszechności i wolności. Wezwanie elfów jest powszechne - dotyczy całego ludu - każdy bez wyjątku jest zaproszony do wyruszenia w drogę i osiągnięcia jej celu. Odpowiedź na to wezwanie jest jednak uzależniona od decyzji każdego z nich. Wielu postanawia pozostać i nie wyruszać w drogę ${ }^{24}$. Tak zwane Credo Nicejsko-konstantynopolitańskie wyraża wiarę w Kościół powszechny - czyli otwarty na wszystkich ludzi wszystkich czasów. Wszyscy bowiem ludzie są wezwani do Zbawienia (por. Mt 28,19-20 $)^{25}$. Decyzja jednak co do przystapienia do Kościoła, wejścia na Drogę Zbawienia jest ze swej natury wolną, indywidualną decyzją każdego człowieka, i musi być podjęta bez przymusu ${ }^{26}$.

Wspólnota

Bardzo ważny jest też motyw wspólnej drogi. Elfowie idą w trzech hufcach - szczepach. Różnią się między sobą, ale połączeni są wspólnotą drogi i celu. W długim marszu nawiązują relacje i wpływają na siebie wzajem-

${ }^{22}$ Por. tamże, 74.

${ }^{23}$ Por. Lumen gentium, nr 9.

${ }^{24}$ Por. Tolkien, Silmarillion, 75.

${ }^{25}$ Por. Lumen gentium, nr 39.

26 „Deklaracja o wolności religijnej Dignitatis humanae”, $\mathrm{nr} 2$, w Sobór Watykański II, Konstytucje, dekrety, deklaracje. 
nie $^{27}$. Kościół również w pierwszej kolejności nie jest instytucją ani organizacją, lecz wspólnotą pielgrzymującego ludu. Wspólnotą wspólnot. Tworzące go grupy i poszczególni jego członkowie jakkolwiek bardzo zróżnicowani, pozostają związani wzajemną miłością i solidarnością ${ }^{28}$.

\section{Wstawiennictwo}

Wiąże się z tym jeszcze jeden piękny aspekt opowieści - mianowicie prośby Noldorów o umożliwienie przeprawy Telerim. Noldorowie jako ci, którzy wcześniej dotarli do celu, wstawiają się za tymi, którzy zatrzymali się na chwilę w drodze. Racją takiego wstawiennictwa jest tęsknota za Telerimi, z którymi wiązały ich serdeczne więzy przyjaźni ${ }^{29}$. Można tu widzieć obraz Świętych obcowania, jedności Kościoła Triumfującego z Pielgrzymującym, modlitw Zbawionych za tymi, którzy są jeszcze w drodze, zwłaszcza zaś za tymi, którzy potrzebuja pomocy w dotarciu do celu. Motywowane są one miłością Boga napełniającą Kościół wszystkich czasów przez Ducha Świętego oraz więzami wspólnej drogi i braterskiej solidarności ${ }^{30}$.

Wspótpraca z taska

Wyraźnie widoczne w przypadku Wielkiej Wędrówki pozostają dwa konieczne działania. $\mathrm{Z}$ jednej strony elfowie podejmują niemały wysiłek podróży, z drugiej - nie osiągnęliby celu wędrówki bez działania Valarów, którzy na specjalnej wielkiej wyspie przenoszą ich ostatecznie do Valinoru. W życiu chrześcijanina i istnieniu Kościoła nieustannie nakładają się i wzajemnie warunkują działanie Boże - łaska i działanie ludzkie. Nie znoszą one siebie nawzajem i oba są konieczne dla osiągnięcia celu, jakim jest Zbawienie ${ }^{31}$.

Droga

Sama droga elfów jest zachwycająca, chociaż nie wolna od trudów i niebezpieczeństw. Wielu z wędrujących, może nie całkiem będąc świadomymi, co czeka ich na miejscu, do którego zmierzają, przedkłada samo wędrowanie nad jego cel, bardziej się go obawiając niż oczekując ${ }^{32}$. Droga członków Kościoła, jaką jest życie, również jest pełna zarówno piękna, jak i niebezpie-

27 Por. Tolkien, Silmarillion, 76-77.

${ }^{28}$ Por. Lumen gentium, nr 7 i 9.

${ }^{29}$ Por. Tolkien, Silmarillion, 81.

${ }^{30}$ Por. Lumen gentium, 49.

${ }^{31}$ Kwestia relacji łaska-,,zasługa” była oczywiście w historii Kościoła obszernie dyskutowana. Por. Zastuga, w Karl Rahner i Herbert Vorgrimler, Maty stownik teologiczny (Warszawa: PAX, 1996).

${ }^{32}$ Por. Tolkien, Silmarillion, 76. 
czeństw i jako taka ma swoją wartość. Wielu z nas jednak doświadcza takiego przywiązania do życia, połączonego z obawą przed nieznanym, które czeka nas za bramą śmierci, że pragnie kontynuować tę drogę za wszelką cenę, nie wiążąc na co dzień nadziei z jej celem. W skali powszechnej widać natomiast obawę przed „Końcem Świata” zamiast oczekiwania Paruzji.

\section{$\mathrm{Cel}$}

Na koniec warto poświęcić trochę miejsca samemu celowi podróży. Valinor jest krainą opromienioną światłem Drzew - jest to światło nieskażone ${ }^{33}$. Jest też krainą Valarów - Potęg, bogów ${ }^{34}$. Wreszcie jest krainą, gdzie elfów czeka szczęśliwe i twórcze życie ${ }^{35}$. Celem istnienia Kościoła jest doprowadzenie wszystkich ludzi do Nieba, rozumianego jako przebywanie w Bożej Obecności w głębokiej relacji z Bogiem. Biblia mówi w tym kontekście o mieszkaniu w domu Ojca (por. J 14,1-2). Jest to współprzebywanie z Jezusem - Światłością Prawdziwą (por. J 1,1-14). Jest pełnym, szczęśliwym i wiecznym życiem w Duchu Ożywicielu (J 7,37-39).

\section{NADZIEJA ZBAWIENIA}

Dodatkowo warto przyjrzeć się sposobowi opisu trzech grup elfów wyznaczonych poprzez ich odpowiedź na wezwanie do Valinoru. Po pierwsze - są ci, którzy zrezygnowali z wędrówki ze strachu przed domniemanymi groźbami któregoś z etapów podróży. Znikają z areny dziejów i słuch o nich ginie. Nie są oni jednoznacznie potępieni, jednak motyw braku pamięci o nich i jakiegokolwiek ich dziedzictwa w dalszym ciągu opowieści jest niezwykle wymowny $^{36}$. Po drugie - wyraźnie należy odróżnić od nich tych, którzy zdecydowali się nie wyruszać w drogę lub zatrzymali się w trakcie wędrówki ze względu na jakieś dobro lub piękno, które szczególnie umiłowali ${ }^{37}$. Nazywani są Elfami Ciemności ${ }^{38}$, jednak cieszą się swego rodzaju przychylnością autora. Odgrywają oni ważną rolę w dalszej historii, chwalone jest ich

\footnotetext{
${ }^{33}$ W odróżnieniu od światła Słońca i Księżyca, które utworzone zostały później, już po skażeniu Drzew przez Melkora. Por. Tolkien, Silmarillion, 58-59, 124-127.

${ }^{34}$ Por. Tolkien, Silmarillion, 58.

${ }^{35}$ Por. tamże, 82-85.

${ }^{36}$ Por. tamże, 76.

${ }^{37}$ Por. tamże, 75, 78-79, 81-82.

${ }^{38}$ Por. tamże, 76.
} 
męstwo w stawianiu oporu złu. Ostatecznie też - pod koniec trzeciej ery wielu z nich odpływa do Valinoru ${ }^{39}$. Po trzecie - istnieje grupa tych, którzy na wezwanie odpowiedzieli i osiągnęli cel. Po długiej wędrówce i licznych trudach dotarli do Valinoru i cieszyli się światłem Drzew $^{40}$. Z tego powodu nazywani są Elfami Światła.

Jeśli przeniesiemy te kategorie na ludzkość i jej odniesienie wobec Kościoła, otrzymujemy ciekawy obraz. Wyraźnie pewny jest los Świętych - tych, którzy przyjęli orędzie Ewangelii i wytrwali wiernie na drodze Kościoła. Nierozstrzygnięty jest los tych, którzy pozostają poza Kościołem lub się od niego odłączyli. Tu jednak zasadniczą kwestią pozostaje wewnętrzna postawa. Wyraźna jest nadzieja dla tych, którzy są wierni dobru i pięknu. Natomiast postawa lęku, wewnętrznego „zakrzywienia” do siebie samego i niechęć do podejmowania trudów silniejsza niż pragnienie dobra, nie ma przed sobą przyszłości. Mamy tu więc obraz bardzo wyważony, ostrożny, ale i pełen nadziei, także dla tych, którzy znajdują się poza Kościołem instytucjonalnym ${ }^{41}$.

\section{PODSUMOWANIE}

W ramach podsumowania warto podkreślić następujące kwestie.

Legendarium Tolkiena może być interpretowane w duchu katolickim. Poszczególne fragmenty i postaci moga stanowić pomoc w przyjęciu orędzia Ewangelii. Całość natomiast ukazuje, przy swojej fantastycznej stylistyce, dzieje świata otwarte na dopełnienie w Jezusie Chrystusie. Taka interpretacja pozostaje zgodna z zamysłem samego autora.

Popularna w teologii patrystycznej i średniowiecznej metoda typu może być nadal żywa i owocna w teologii współczesnej. Jej rozsądne zastosowanie pozwala zobaczyć Chrystusa jako wypełnienie dziejów. Ostrożna aplikacja tej metody do współczesnych dzieł kultury pozwala zobaczyć je jako wyrażające tęsknotę człowieka i ludzkości za Ewangelią, i potencjalne przygotowanie do jej przyjęcia.

Kategoria typu pozostaje adekwatną w chrześcijańskiej interpretacji prac Tolkiena ze względu na mityczny charakter dzieła, jak również podejście 383.

${ }^{39}$ Por. John R.R. Tolkien, Władca Pierścieni. Powrót Króla (Warszawa: Amber, 2012), 382-

${ }^{40}$ Por. Tolkien, Silmarillion, 82-85.

${ }^{41} \mathrm{~W}$ jakimś sensie wpisuje się on w Rahnerowski koncept ,,anonimowego chrześcijaństwa”. Por. Chrześcijaństwo anonimowe, w Rahner i Vorgrimler, Mały stownik teologiczny. 
samego autora co do przekazu prawdy religijnej poprzez opowieść. Złożone, trudne w jednoznacznej interpretacji i wymykające się prostej alegoryzacji, zachowują głęboki bagaż religijnej treści.

\section{BIBLIOGRAFIA}

Androsik, Alena. Misja Powiernika Pierścienia jako przykład realizacji powołania chrześcijańskiego. Studium teologicznomoralne na podstawie „Władcy Pierścieni” J.R.R. Tolkiena. Lublin: Polihymnia, 2015.

„Deklaracja o wolności religijnej Dignitatis humanae”. W Sobór Watykański II. Konstytucje, dekrety, deklaracje. Tekst polski - nowe tłumaczenie. 410-421. Poznań: Pallottinum, 2002.

Gulisano, Paolo. C.S. Lewis. Od Narnii do Ewangelii. Poznań: W drodze, 2006.

Hilary z Poitiers. O tajemnicach. Warszawa: Wydawnictwo Uniwersytetu Kardynała Stefana Wyszyńskiego, 2002.

Ireneusz z Lyonu. Adversus Haereses. Pelplin: Bernardinum, 2018.

„Konstytucja dogmatyczna o Kościele Lumen gentium”. W Sobór Watykański II. Konstytucje, dekrety, deklaracje. Tekst polski - nowe ttumaczenie. 104-166. Poznań: Pallottinum, 2002.

Pismo Święte Starego i Nowego Testamentu Biblia Tysiaclecia. Poznań: Pallottinum, 2008.

Rahner, Karl i Herbert Vorgrimler. Mały słownik teologiczny. Tłum. Tadeusz Mieszkowski. Warszawa: PAX 1996.

Simonetti, Manlio. Między dostownościq a alegoria: przyczynek do historii egzegezy patrystycznej. Kraków: WAM, 2000.

Stownik wiedzy biblijnej, red. Bruce M. Metzger, Michael D. Coogan. Warszawa: Vocatio, 2004.

Tolkien, John R.R. Listy. Tłum. Agnieszka Sylwanowicz. Warszawa: Prószyński i S-ka, 2010.

Tolkien, John R.R. Silmarillion. Tłum. Maria Skibniewska. Warszawa: Amber, 2008.

Tolkien, John R.R. Władca Pierścieni. Drużyna Pierścienia. Tłum. Maria Skibniewska. Warszawa: Amber, 2012.

Tolkien, John R.R. Władca Pierścieni. Dwie Wieże. Tłum. Maria Skibniewska. Warszawa: Amber, 2012.

Tolkien, John R.R. Władca Pierścieni. Powrót Króla. Tłum. Maria Skibniewska. Warszawa: Amber, 2012.

\section{ŚRÓDZIEMIE „ZAPOWIADAJACE” NOWE PRZYMIERZE. PROPOZYCJA SPOSOBU INTERPRETACJI LEGENDARIUM J.R.R. TOLKIENA}

St res z c z e n i e

Artykuł dotyka zagadnienia możliwości teologicznej interpretacji dzieł kultury na przykładzie dzieł J.R.R. Tolkiena. Wskazuje występujące racje takiej interpretacji oraz towarzyszące jej trudności. Posługuje się, pochodzącą od św. Pawła, kategorią „typu” - zjawiska, osoby lub 
wydarzenia zapowiadającego rzeczywistość Nowego Przymierza. Najpierw przybliża jej sens i historię wykorzystania w teologii, następnie uzasadnia jej zastosowanie do fragmentów prozy Tolkiena. Zasadniczą część artykułu stanowi odczytanie Wielkiej Wędrówki Elfów, opisanej w rozdziałach III-V Silmarillionu, jako obrazu Kościoła Pielgrzymującego. Kluczowe dla takiej interpretacji pozostają elementy takie, jak motyw wezwania, wspólnej drogi czy wzajemnego wstawiennictwa, a także wspaniałość celu wędrówki. Artykuł ukazuje z jednej strony owocność metody typologicznej, z drugiej - możliwość teologicznego wykorzystania dzieł literatury współczesnej.

Słowa kluczowe: literatura; Tolkien; typ; Kościół. 